\title{
Stimulating students' learning motivation: A case study of music education and pedagogy course based on flipped classroom
}

\author{
Rui Ma \\ Beijing City University, China \\ 13661384500@163.com
}

\begin{abstract}
This study reports the results of a case study that investigated the impact of music education and pedagogy course based on flipped classroom on music major students in Beijing City University. The main findings from this study indicated that flipped classroom had a positive impact on stimulating students' learning motivation, which is related to three main themes: studentcentered, peer motivation and deep learning. Although some of these impacts were not always clearly distinguished from the more general experience of higher music education, some effective practical paths had been identified in teaching that link to these three themes in some interrelated contexts. This study raises some important questions, that is, how to stimulate students' learning motivation in the distinctive music discipline, and discusses the direction of further reform of this course based on flipped classroom.
\end{abstract}

Keywords

case study; Music education and pedagogy course; flipped classroom; qualitative research; practical paths; teaching reform

\section{Introduction}

In recent years, information technology has been developing at an unprecedented speed, subverting traditional educational forms and teaching models, and promoting the continuous advancement of educational reforms(Datnow, A., Hubbard, L., \& Mehan, H, 2002). Music theory courses in colleges and universities based on traditional teaching methods cannot keep up with the development of educational informatization on the one hand(Li, F., 2020). On the other hand, they cannot satisfy the learning methods and learning of the post-2000 student group known as the "Internet natives" habit(Stordy, P., 2012). Flipped classroom, as a product of education informatization, will help solve the above dilemmas and has positive practical significance for the exploration of curriculum reform paths(Butzler, K. B., 2014; Crompton, H., \& Traxler, J., 2018; Hou, X., 2019).

The application of flipped classrooms has also been continuously tried in the field of higher music education in China(Shu, T., 2018; Wang, H., 2018; Qu, H., \& Xing, D., 2019). However, the application of flipped classrooms to higher music courses in China is still in the initial stage of exploration. Therefore, understanding the impact of the flipped classroom teaching model on students' learning motivation has become an important link for music educators to optimize the teaching structure and reform the teaching model(Hu Bin., 2018).

\section{Research Purpose}

This article reports the results of a case study investigating the impact of the music education and pedagogy course based on the flipped classroom on music major students in Beijing City University. This research documents the design, process and results of curriculum reform, and explores whether flipped classrooms have an impact on stimulating students' learning motivation(Guo, J., 2019; Zheng, L., Bhagat, K. K., Zhen, Y., \& Zhang, X., 2020).

\section{Curriculum Instructional Design}

The identified case was the music education and pedagogy course (60 hours, 4 credits) based on flipped classroom in Beijing City University. The reason why I chose this course in this University was that at present, China's higher music curriculum mainly adopts the traditional offline teaching mode, which is mainly taught by teachers, which is disconnected from the rapid 
development of education informatization to a certain extent. The teaching method is relatively simple, and the students' learning enthusiasm needs to be further mobilized. The flipped classroom teaching reform of this course in this school provided an effective practical path for the teaching reform of higher music education.

The music education and pedagogy course was a basic compulsory course for music majors, which started in 2011 when the University set up this major. In the past 10 years, the curriculum has been continuously improved and developed. Through the study of the essential characteristics and social functions of music education, the curriculum structure of music education, music teaching methods, foreign famous music teaching system and other knowledge, students can understand music education theory, master teaching ideas and teaching methods, and lay a good theoretical foundation for music education practice in the future.

Starting from the fall semester of 2020, classroom teacher has used the flipped classroom teaching model in their courses(Mok, H. N., 2014). Compared with the traditional curriculum featuring face-to-face instruction by teachers, the revised teaching design of the curriculum has the following characteristics:

\section{A. Resource authority was professional}

Pre-class learning resources were an important part of teaching and directly affected the quality of students' self-study. This study used the school's UMOOC platform to establish systematic curriculum resources. Some of the course resources were selected from the national quality course "Basics of Music Education".It was an online MOOC led by Professor Xie Jiaxing of the China Conservatory of Music, which absorbed the latest academic research results of music education at home and abroad in recent years. Selected videos from this MOOC helped students learn from a high starting point and professionalism. At the same time, part of the curriculum resources were fully integrated with the characteristics of the students of the school, recorded by the project team, taking into account the characteristics and differentiation of students' academic conditions, and ensuring the unity of common characteristics and individual characteristics.

\section{B. Pay attention to process assessment and evaluation}

Teaching evaluation runs through the whole process before, during and after class. The diversification of evaluation subjects was emphasized, covering various evaluation forms including self-evaluation of students, mutual evaluation among individual students, mutual evaluation among groups, and teacher evaluation. The content of evaluation was diversified, comprehensively evaluating students' preview situation, classroom participation, and learning results, and affirming every effort of students in the learning process.

In the course, the main learning activities of students included:

- Watching the weekly videos released by the teacher, and viewing relevant texts available for download;

- Reading the text recommended by the teacher and browsing the course;

- Participate in discussions in online learning forums, ask questions or answer questions for others;

- Complete feedback before class;

- Complete group discussion and homework;

- Complete relevant teaching design and conduct peer evaluation on others' teaching design works.

\section{Method}

Participants in the study included 37 undergraduates majoring in music from September 2020 to January 2021 who took the course "Music Education and Pedagogy". The research focused on interview data and supporting documents. Observation notes were the tool to examine the context and relationship of my researcher-self to the data collected. 
This study conducted 12 semi-structured interviews to understand the learning motivation of the respondents. Interview is the primary way for researchers to "investigate an educational process through the experience of the individual people who carry out the process"(Seidman, I., 2006). Interviews provide in-depth information about participants' experiences and opinions on specific topics(Turner III, D. W., 2010). The semi-structured interview includes pre-determined questions and further in-depth questions based on the answers of the interviewees (Daymon, C., \& Holloway, I., 2010), which are used for in-depth understanding of the subjects (Dane, F. C.,2011). I used the purposeful sampling method to select participants, which enabled us to sample in a strategic way and ensure the diversity of the sample(Bryman, A., 2016; Cohen, L., Manion, L., \& Morrison, K., 2017).

Supporting documents included students' assignments (including online and offline assignments) and videos (including classroom activities and presentation of learning outcomes).As part of the coursework content, before and after class, students would record and discuss their learning experience by writing an online learning log. The teacher did not have special regulations on the number of logs, the length of the logs, and the language used. It was only required for students to record their true feelings and experiences in the course.

In the two weeks after collecting the data, I transcribed all the audio and video, and prepared the transcripts for analysis.I read the coherent transcript and then completed the analysis in MAXQDA, which is a Computer-Assisted Qualitative Data Analysis System (CAQDAS). I completed the initial round of coding as a way of condensing data into chunks using descriptive and inferential labels. After coding each transcript, I wrote a continuous analysis memo and transcript summary to capture and stimulate data analysis(Auerbach, C., \& Silverstein, L. B.,2003; Harding, J. ,2018; Gibbs, G. R.,2018). In order to ensure the reliability of the coding, the second researcher was asked to complete the first round of coding(Morse, J. M., Barrett, M., Mayan, M., Olson, K., \& Spiers, J.,2002; Campbell, J. L.,
Quincy, C., Osserman, J., \& Pedersen, O. K.,2013). After coding the transcript and writing the memo and summary, I formed the axial codes as a means of investigating the relationship between the categorical ideas in the transcript(Charmaz, K., 2006), in order to form a more comprehensive and clear explanation.

\section{Findings}

\section{A. Student oriented}

Learning arrangement. In the whole process of flipped classroom teaching, it provided space for students to give full play to, and highlighted the main status of students. I think my study schedule is relatively free. For example, I can control the pace of the video by myself. ...I can also use the chat software to ask the teacher or classmates for help and answer my own questions at any time.(S2)

Learning experience. The video provided by the teacher is not long, and it takes a little time to complete, which is very fulfilling. I think this kind of class is much more efficient. Moreover, when the teacher asks questions, it will not be as nervous as a normal classroom.(S6)

Learning convenience. It has the advantage of facilitating learning and reducing the reliance on textbooks during preview and review. It is also more convenient to submit homework and other materials by checking the learning materials on the UMOOC platform.(S11)

\section{B. Peer motivation}

The curriculum gave full play to the role of "peer motivation", by increasing the interest of learning activities and the divergence of the problems to be solved, creating a good learning atmosphere for the curriculum; through group cooperation, intergroup competitions, brainstorming, debate competitions, etc. This kind of form promotes competition among groups and full cooperation within the group.

Some students have many ideas, some are very careful and good at checking and filling 
vacancies, some are good at leading everyone, and some are good at concluding remarks. Everyone uses their strengths...(S7)

When the group completes the task, we often use the method of teamwork to find the students who are good at the field to lead everyone, grasp the key points and difficulties of the task given by the teacher, and break them one by one.(S10)

\section{Deep learning}

Outside of class, learning content was mainly focused on shallow learning, typically direct teaching through video technology, and students were required to give feedback on video learning. In class, deep learning was mainly carried out, and teaching activities were carried out through key learning frameworks such as teachers and peers. Through the close integration of pre-class (watching instructional videos, targeted pre-class exercises) and in-class (quick and small assessments, problem-solving to complete internalization, summary and feedback), the internalization of students' knowledge and strengthening Students' understanding, digestion and absorption of theories.

Promote the understanding of the theory. From the very beginning, I didn't quite understand those theoretical aspects, and then I deepened a little bit to understand the theory, and then I started teaching and practicing in class. ...I think this process has improved a lot.(S3)

Promote the flexible learning and application of pedagogy. It will serve as a preview for some of the content I will learn in the next class. .....I especially like class activities such as analyzing lesson examples and creating Orff's momentum.(S1)

\section{Discussions}

It is true that the curriculum reform is not accomplished overnight. There is still room for improvement in curriculum design, and the arrangement of student learning tasks still needs to be fine-tuned. Although the flexibility, autonomy, and diversification of the flipped classroom format were popular among students(McNally, B., Chipperfield, J., Dorsett, P., Del Fabbro, L., Frommolt, V., Goetz, S., ... \& Rung, A., 2017), the students also mentioned some of the problems in the interviews. For example, the login of the UMOOC platform was affected by factors such as network speed, platform stability, and mobile phone model, which affected the learning experience of students to a certain extent. Individual groups were dependent on each other, likes and dislikes work, and the division of labor within the group was not reasonable. A small number of students spent more time on accumulating video browsing time in online courses, and they had no time to understand and think deeply about the content of the course. As a result, there were few things to remember after learning, and the learning effect was not good.

According to the first round of curriculum reform, further improve various teaching documents and teaching resources; according to the characteristics of students in different classes, more accurate teaching in accordance with their aptitude will be the direction of this research to continue to deepen the reform.

\section{Conclusion}

The finding of the study reveal that the curriculum reform of music education and pedagogy course based on the flipped classroom has achieved good teaching results and harvested phased research results. Using the flipped classroom teaching model to carry out curriculum reform, by transforming shallow knowledge into pre-class learning resources, it has well "liberated" the time and space of the actual classroom. In the actual classroom, the role of "peer motivation" is played, with teachers as the leading and students as the main body, focusing on higher-level learning tasks, promoting the internalization of students' knowledge to achieve deep learning, and realizing the improvement of overall learning performance.

\section{Limitations and Future Studies}

The experimental design adopted in this study was a case study, and the external validity of the experiment was limited. In future research, 
controlled experiments in different classes or large sample tests can be conducted to further verify the effectiveness of flipped classrooms.

\section{Funding}

This research is one of the research results of the Beijing City University's 2020 Educational Science Research Project Funding Project. The project name is "Research on the Curriculum Reform of Music Education and Pedagogy Course Based on Flipped Classroom", and the project number is JYC20201003.

\section{Notes On Contributor}

Dr. Rui Ma is currently a lecturer at the Faculty of Performance, Beijing City University, Beijing, China. Her research interests deal with music curriculum and teaching theory, comparative study of music education and professional development of music teachers.

\section{ORCID iD}

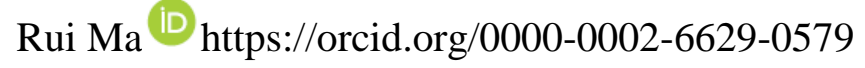

\section{References}

[1] Bryman, A. (2016). Social research methods. Oxford university press.

[2] Butzler, K. B. (2014). The effects of motivation on achievement and satisfaction in a flipped classroom learning environment. Northcentral University.

[3] Charmaz, K. (2006). Constructing grounded theory: A practical guide through qualitative analysis. sage.

[4] Chen Yi, \& Zhao Chengling. (2014). Instructional design and application research based on the flipped classroom model (Doctoral dissertation).

[5] Cohen, L., Manion, L., \& Morrison, K. (2017). Research methods in education. routledge.
[6] Dane, F. C. (2011). Evaluating research: Methodology for people who need to read research. Sage.

[7] Daymon, C., \& Holloway, I. (2010). Qualitative research methods in public relations and marketing communications. Routledge.

[8] Guo, J. (2019). The use of an extended flipped classroom model in improving students' learning in an undergraduate course. Journal of Computing in Higher Education, 31(2), 362-390.

[9] Herreid, C. F., \& Schiller, N. A. (2013). Case studies and the flipped classroom. Journal of College Science Teaching, 42(5), 62-66.

[10] Hu Bin. (2018). An Analysis of the Flipped Classroom Model of Music Fundamental Theory Education in the Internet Era: A Review of Khan Academy of Flipped Classroom: Educational Revolution in the Internet Age. Chinese Journal of Education, (5).

[11] Huang Yan, Jiang Ling, \& Huang Lei. (2014). Research on the Application of Flipped Classroom in the Experimental Teaching of "Modern Educational Technology". China Audio-visual Education, (4), 110-115.

[12] Jun, Q. I. (2015). The Rise, Development and Process Design of "Flipped Classroom" in US and Its Implication. Comparative Education Review, 1.

[13] Li Peiyuan. (2016). Flipped classroom based on MOOC and its teaching research. Education, (06), 00186-00186.

[14] McNally, B., Chipperfield, J., Dorsett, P., Del Fabbro, L., Frommolt, V., Goetz, S., ... \& Rung, A. (2017). Flipped classroom experiences: student preferences and flip strategy in a higher education context. Higher Education, 73(2), 281-298.

[15] Mok, H. N. (2014). Teaching tip: The flipped classroom. Journal of information systems education, 25(1), 7. 
[16] Qu, H., \& Xing, D. (2019, July). Music Aesthetics Course Teaching Reform Based on Flipped Classroom Model. In International Conference on Applied Human Factors and Ergonomics (pp. 190199). Springer, Cham.

[17] Seidman, I. (2006). Interviewing as qualitative research: $A$ guide for researchers in education and the social sciences. Teachers college press.

[18] Shibukawa, S., \& Taguchi, M. (2019). Exploring the difficulty on students' preparation and the effective instruction in the flipped classroom. Journal of Computing in Higher Education, 31(2), 311-339.

[19] Shu, T. (2018). Application of Moocbased Flipped Classroom in the Teaching Reform of Piano Course. Educational Sciences: Theory \& Practice, 18(5).

[20] Tucker, B. (2012). The flipped classroom. Education next, 12(1), 82-83.

[21] Turner III, D. W. (2010). Qualitative interview design: A practical guide for novice investigators. The qualitative report, 15(3), 754-760.

[22] Wang, H. (2018). The Application of Flipped Classroom in Colleges and Universities Piano Collective Classes. Creative Education, 9(7), 1021-1026.

[23] Yilmaz, R. (2017). Exploring the role of $e$ learning readiness on student satisfaction and motivation in flipped classroom. Computers in Human Behavior, 70, 251260.

[24] Zhang Yang, \& Meng Zecha. (2013). The value, limits and symbiosis of "Guiding Learning Plan Teaching" and "Flipped Classroom". Global Education Outlook, 7, 10-17.

[25] Zheng, L., Bhagat, K. K., Zhen, Y., \& Zhang, X. (2020). The Effectiveness of the Flipped Classroom on Students' Learning Achievement and Learning Motivation. Journal of Educational Technology \& Society, 23(1), 1-15.
[26] Zheng, X. L., Kim, H. S., Lai, W. H., \& Hwang, G. J. (2020). Cognitive regulations in ICT - supported flipped classroom interactions: An activity theory perspective. British Journal of Educational Technology, 51(1), 103-130. 